\title{
MIRLET7B Pre-miRNA
}

National Cancer Institute

\section{Source}

National Cancer Institute. MIRLET 7B Pre-miRNA. NCI Thesaurus. Code C82740.

MIRLET 7B pre-miRNA is an oligonucleotide that is encoded by the human MIRLET7B gene and has a role in the regulation of gene expression. 